\title{
Pengaruh pelatihan menggosok gigi dengan pendekatan Program Pembelajaran Individual (PPI) terhadap peningkatan status kebersihan gigi dan mulut pada anak disabilitas intelektual sedang
}

\author{
Leny Pratiwi Arie Sandy*, Bambang Priyono**, Niken Widyanti*** \\ *Program Studi Pascasarjana, Fakultas Kedokteran Gigi, Universitas Gadjah Mada, Yogyakarta, Indonesia \\ ${ }^{* *}$ Departemen IImu Kedokteran Gigi Pencegahan dan IImu Kesehatan Gigi Masyarakat, Fakultas Kedokteran Gigi, Universitas Gadjah \\ Mada, Yogyakarta, Indonesia \\ ***Departemen IImu Kedokteran Gigi Pencegahan dan IImu Kesehatan Gigi Masyarakat, Fakultas Kedokteran Gigi, Universitas \\ Gadjah Mada, Yogyakarta, Indonesia \\ *JI Denta No 1, Sekip Utara, Yogyakarta, Indonesia; e-mail: lenypratiwi@gmail.com
}

Submisi: 4 November 2015; Penerimaan: 8 Juni 2016

\begin{abstract}
ABSTRAK
Anak dengan disabilitas intelektual (DI) merupakan kelompok anak yang memiliki keterbatasan intelektual, kemampuan adaptif, kemampuan sosial dan kemampuan beraktifitas (praktis). Pelatihan menggosok gigi dengan pendekatan Program Pembelajaran Individual (PPI) merupakan salah satu strategi yang menitik beratkan kondisi dan motivasi masing-masing siswa didik. Penelitian ini bertujuan untuk mengetahui pengaruh pelatihan cara menggosok gigi melalui pendekatan Program Pembelajaran Individual (PPI) terhadap status kebersihan gigi dan mulut. Metode penelitian ini yaitu kuasi eksperimental dengan desain subyek tunggal (single subyek design). Responden dalam penelitian ini yaitu 3 orang (R1, R2, R3) diambil sesuai kriteria yang sudah ditentukan. Metode pengumpulan data yang digunakan yaitu observasi. Status kebersihan gigi dan mulut diukur menggunakan indeks PHP-M (Patient Hygiene Performance-Modified) dari Martens dan Meskin (1972). Analisis datanya menggunakan analisis deskriptif. Hasil penelitian ini menunjukkan setelah dilakukan pelatihan menggosok gigi selama 6 minggu didapatkan adanya penurunan skor plak yang rendah. Status kebersihan gigi dan mulut ke-3 responden didapatkan R1 dan R2 pada kategori sedang, sedangkan R3 pada kategori buruk. Pelatihan cara menggosok gigi menggunakan pendekatan Program Pembelajaran Individual (PPI) berpengaruh terhadap peningkatan status kebersihan gigi dan mulut.
\end{abstract}

Kata kunci: disabilitas intelektual, Program Pembelajaran Individual (PPI), status kebersihan gigi dan mulut

\begin{abstract}
Effect of training on tooth brushing using Individual Educational Programme (IEP) approach to increase of oral hygiene status in children of moderate intellectual disability (ID). Children with Intellectual Disability (ID) have limited abilities (social, adaptive and practical) and limited intellect. Teaching these children to brush their teeth using the Individualized Educational Programme (IEP) approach is a strategy which focuses on the condition and motivation of each student. The purpose of this research was to understand how tuition in the techniques of toothbrushing by IEP influences oral hygiene in medium level ID students. This research method is to master the experiment by single subject design. The respondents in this research were 3 people $(R 1, R 2, R 3)$ taken according to the predetermined criteria. Data collection method used was by observation. Oral hygiene was measured using the PHP-M (Patient Hygiene Performance-Modified) index from Martens and Meskin (1972). The data analysis used descriptive analysis. The result of the study showed there was after training on tooth brushing for 6 month is decrease plaque score. Oral hygiene status for 3 repondent is $R 1$ and $R 2$ in medium category, R3 in bad category. Training on method of tooth brushing using IEP approach affected increase of oral hygiene status.
\end{abstract}

Keywords: intellectual disability, Individualized Educational, Programme (IEP), oral hygiene status

\section{PENDAHULUAN}

Anak berkebutuhan khusus merupakan kelompok anak yang mengalami keterbatasan baik secara fisik, mental, intelektual, sosial maupun emosional. Kondisi karakteristik ini berpengaruh terhadap proses pertumbuhan dan perkembangan anak. ${ }^{1}$ Anak disabilitas intelektual (DI) merupakan salah satu anak kelompok berkebutuhan khusus yang memiliki ciri tingkat kecerdasan di bawah rata-rata. ${ }^{2}$ Disabilitas intelektual merupakan suatu gangguan selama periode perkembangan yang ditandai dengan defisit fungsi intelektual, adaptif, sosial dan praktis. ${ }^{3}$

Data Badan Pusat Statistik (BPS) tahun 2003 menyebutkan bahwa jumlah anak berkebutuhan 
khusus di Indonesia sekitar $0,7 \%$ dari total jumlah penduduk sebesar 211.428 .572 atau sebanyak 1.480.000 jiwa. ${ }^{4}$ Tahun 2007 survei yang dilakukan oleh Pusat Data dan Informasi Departemen Sosial menyebutkan bahwa jumlah populasi anak berkebutuhan khusus yaitu sekitar $3,11 \%$ dari total penduduk Indonesia. ${ }^{5}$

Kelompok anak DI sedang memiliki kemampuan perawatan diri yang lebih rendah dibandingkan kelompok DI ringan, kondisi ini disebabkan karena kelemahan motorik halus dan kondisi otot-otot tangan yang kaku. ${ }^{6}$ Salah satu kegiatan perawatan diri atau bina diri yaitu kegiatan menggosok gigi. Tujuan pembelajaran bina diri atau merawat diri yaitu siswa diharapkan mampu mengembangkan sikap dan kebiasaan mengurus kebutuhan dasar secara mandiri dan tidak bergantung pada orang lain atau pengasuh. ${ }^{7}$

Kemampuan perawatan diri yang rendah mengakibatkan status kesehatan yang rendah pula, kelompok anak DI memiliki kebutuhan perawatan gigi dan mulutyang tinggi dibandingkan dengan anak normal pada umumnya. ${ }^{8}$ Sebagian besar memiliki permasalahan pada rendahnya status kebersihan gigi dan mulut dan tingginya penyakit periodontal. Penumpukan bakteri plak pada gigi merupakan penyebab utama penyakit periodontal. Produk dari bakteri tersebut dapat menyebabkan kerusakan jaringan epitel dan jaringan ikat serta sel-sel yang didalamnya. ${ }^{9}$ Plak merupakan suatu akumulasi dari bakteri dan matrik interseluler yang membentuk biofilm, melekat pada permukaan gigi serta struktur oral lainnya. ${ }^{10}$ Plak secara klinis merupakan suatu lapisan tipis yang berwarna kuning ke abu-abuan melekat erat pada permukaan jaringan keras gigi, restorasi maupun alat prostetik. ${ }^{11}$

Masih rendahnya kemampuan menggosok gigi serta rendahnya status kebersihan gigi dan mulut yang rendah maka kelompok ini memerlukan pelatihan atau pembelajaran menggosok gigi secara lebih baik. Kondisi karakteristik yang berbeda-beda dan unik menjadi suatu kendala besar dalam proses pembelajaran atau pelatihan kelompok ini yang dapat berdampak pada capaian tujuan pembelajaran. Pelayanan pembelajaran kelompok DI tidak didasarkan semata-mata pada angka Intelligence
Quotient (IQ) melainkan juga pertimbangan dari sisi kemampuan, masalah dan kebutuhan nyata dari kondisi yang dihadapi anak DI. ${ }^{12}$

Program Pembelajaran Individual (PPI) merupakan pendekatan pelayanan khusus dalam pembelajaran anakDI. ${ }^{13}$ Program ini menawarkan cara dalam proses pembelajaran siswa yang sesuai kondisi dan motivasi masing-masing siswa didik. ${ }^{12}$ Menurut Delphie (2006) PPI diarahkan pada hasil akhir capaian pembelajaran yang berupa kemandirian tiap siswa dalam melakukan setiap tugas. PPI memiliki tahapan dalam proses kegiatannya, menurut Kitano dan Kirby (1986. cit Rochyadi dan Alimin, 2005) prosedur Program Pembelajaran Individu (PPI) memiliki lima tahapan yaitu: 1) pembentukan tim PPI, 2) menilai kebutuhan khusus anak, 3) mengembangkan tujuan jangka panjang dan jangka pendek, 4) merancang metode dan prosedur pembelajaran, 5) menentukan evaluasi pembelajaran. ${ }^{14}$

Pelatihan menggosok gigi dengan menerapkan Program Pembelajaran Individual (PPI) yang dilakukan di SLB Negeri Pembina Yogyakarta ini diharapkan mampu meningkatkan kemampuan bina diri sehingga memberikan dampak pada peningkatan status kebersihan gigi dan mulut anak DI sedang. Adapun tujuan penelitian ini yaitu untuk mengetahui pengaruh pelatihan cara menggosok gigi melalui pendekatan Program Pembelajaran Individual (PPI) terhadap status kebersihan gigi dan mulut anak disabilitas intelektual sedang.

\section{METODE PENELITIAN}

Jenis penelitian yaitu kuasi eksperimental (quasi experiment) ini telah mendapatkan persetujuan dari Tim Etik Penelitian Fakultas Kedokteran Gigi UGM No.00119/KKEP/FKG-UGM/EC/2015. Penelitian ini lebih difokuskan pada penelitian dengan desain subjek tunggal (single subyek design). Responden penelitian ini yaitu 3 orang dengan kriteria anak DI sedang, tidak mengalami kecacatan anggota tubuh, mampu memahami kata sederhana, gigi tidak berjejal, mempunyai minimal 2 gigi indeks dari 6 gigi indeks. Alat ukur penelitian yang digunakan untuk mengukur status kebersihan gigi dan mulut yaitu menggunakan indek PHP-M dari Martens dan Meskin (1972, cit Sriyono, 2007) dengan skor terendah 
0 dan skor tertinggi 60. Adapun pengkategorian skor sebagai berikut: kategori baik skor antara $0-20$, kategori sedang skor antara $21-40$, kategori buruk skor antara 41-60. Alat dan bahan penelitian yang digunakan yaitu kaca mulut, pinset, sonde, disclosing solution, kapas, alkohol, gelas kumur. Jalannya penelitian ini yaitu setelah responden ditentukan sesuai kriteria lalu menerapkan proses Program Pembelajaran Individual (PPI) diantaranya yaitu: 1) pembentukan tim PPI yaitu 3 orang tua, 1 guru dan 1 peneliti, 2) menilai kebutuhan anak (base line), 3) mengembangkan tujuan pembelajaran, 4) merancang metode dan prosedur pembelajaran atau pelatihan, 5) evaluasi hasil pelatihan selama 6 minggu yang dilakukan setiap 1 minggu 1 kali yaitu dengan menilai status kebersihan gigi dan mulut setelah dilakukan pelatihan, selanjutnya melakukan pengumpulan dan menganalisa data. Analisa data dalam penelitian ini menggunakan analisa subyek tunggal, dalam analisa data dipaparkan dalam bentuk pembuatan grafik, penggunaan statistik deskriptif dan penggunaan analisa visual.

\section{HASIL PENELITIAN}

Hasil penelitian yang dilakukan pada 3 responden (R1, R2, R3) didapatkan karakteristik ke-3 responden yaitu terdiri dari 1 laki-laki dan 2 perempuan. Rentang IQ ke-3 responden ini sangat variatif yaitu R1: 48, R2: 65 dan R3: 66. Latar belakang orang tua ke-3 responden 2 diantaranya orang tua berpendidikan SMA (R1 dan R2) dan 1 Responden berpendidikan S1 (R3). Adapun hasil penelitian yang didapatkan yaitu karakteristik responden dan status kebersihan gigi dan mulut masing-masing responden sebagai berikut:

\section{Responden 1 (R1)}

Karakteristik responden 1 ber-IQ 48, pendiam, penyesuaian awal agak sulit jika bertemu dengan orang baru, mampu memahami dan mengikuti perintah sederhana, motorik kasar kurang, motorik halus baik, bahasa ibu yang digunakan campur bahasa Jawa dan Indonesia, kemampuan sosial baik, keterampilan menggosok gigi awal yaitu pada kategori sedang. Status kebersihan gigi dan mulut R1 dapat dilihat pada Gambar 1
Gambar 1 menunjukkan status kebersihan gigi dan mulut R1 setelah dilakukan pelatihan selama 6 minggu, didapatkan rerata status kebersihan mulut yaitu 28 (kategori sedang). Rerata penurunan skor plak setiap minggu setelah pelatihan yaitu 7. Bagian permukaan gigi yang masih terdapat penumpukan plak setelah menggosok gigi yaitu permukaan gigi sisi lingual segmen $4,5,6$, sisi palatal 1, 2, 3 dan sisi bukal segmen 4, 6. R1 mampu membersihkan plak gigi dengan baik pada sisi permukaan oklusal segmen 1, 3, 4, 6 dan labial segmen 2, 5 .

\section{Responden 2 (R2)}

Karakteristik responden ber-IQ 65, komunikatif, mampu memahami dan mengikuti perintah sederhana, motorik kasar kurang, motorik halus masih kaku, keseimbangan tangan kanan dan kiri masih belum stabil, bahasa ibu yang digunakan bahasa Indonesia, kemampuan sosial baik, keterampilan menggosok gigi awal yaitu pada kategori buruk. Status kebersihan gigi dan mulut R2 dapat dilihat pada Gambar 2.

Gambar 2 menunjukkan status kebersihan gigi dan mulut R2 setelah dilakukan pelatihan selama 6 minggu, didapatkan rerata status kebersihan mulut yaitu 39 (kategori sedang). Rerata penurunan skor plak setiap minggu setelah pelatihan yaitu 7. Bagian permukaan gigi yang masih terdapat penumpukan plak setelah menggosok gigi yaitu permukaan gigi sisi lingual segmen $4,5,6$, sisi palatal $1,2,3$, sisi bukal segmen 4, 6 dan sisi labial segmen 5. R2 mampu membersihkan plak gigi dengan baik pada sisi permukaan oklusal segmen 6, 4 dan labial segmen 2 .

\section{Responden 3 (R3)}

Karakteristik responden ber-IQ 61, sangat komunikatif cenderung banyak bicara, mampu memahami dan mengikuti perintah sederhana, mudah tidak fokus, motorik halus dan kasar baik, keseimbangan tangan kanan dan kiri sangat baik, banyak gerak, bahasa ibu yang digunakan campur (Bahasa Indonesia dan Jawa), kemampuan sosial yaitu mudah bersosialisasi dengan orang lain, keterampilan menggosok gigi awal yaitu pada kategori sedang. Status kebersihan gigi dan mulut R3 dapat dilihat pada Gambar 3. 


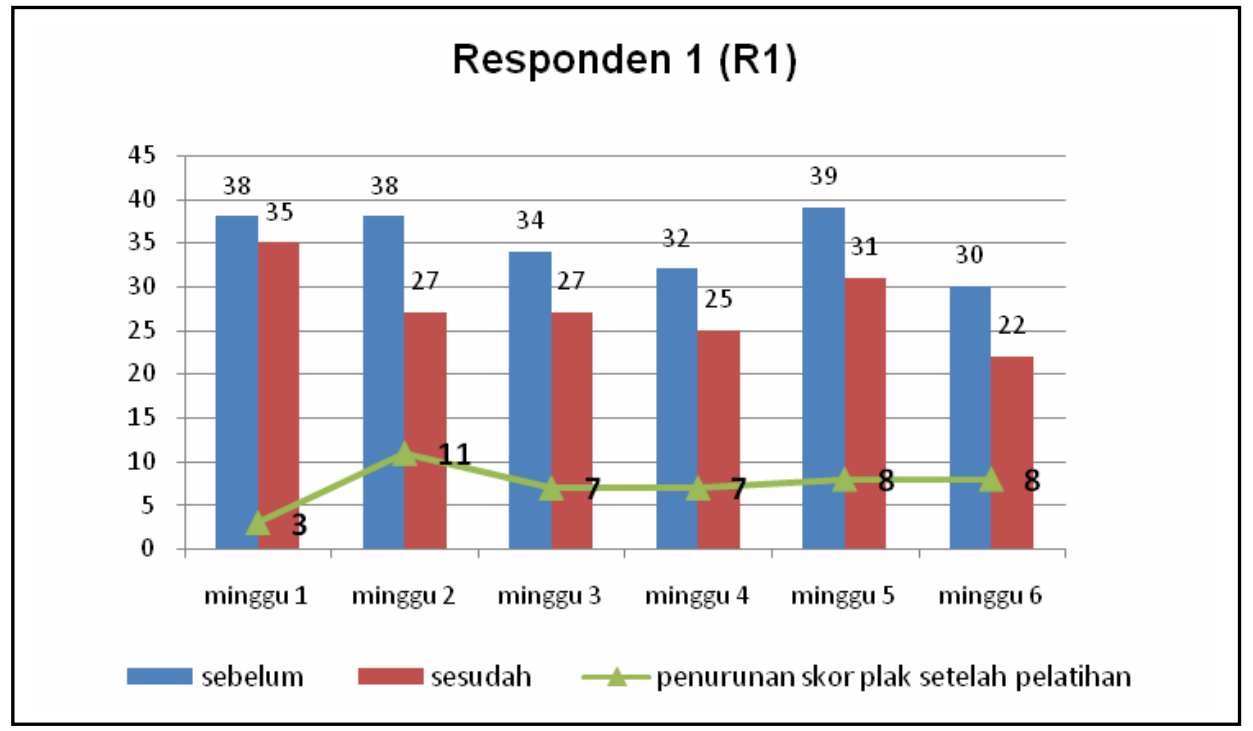

Gambar 1. Status kebersihan gigi dan mulut sebelum dan sesudah pada R1

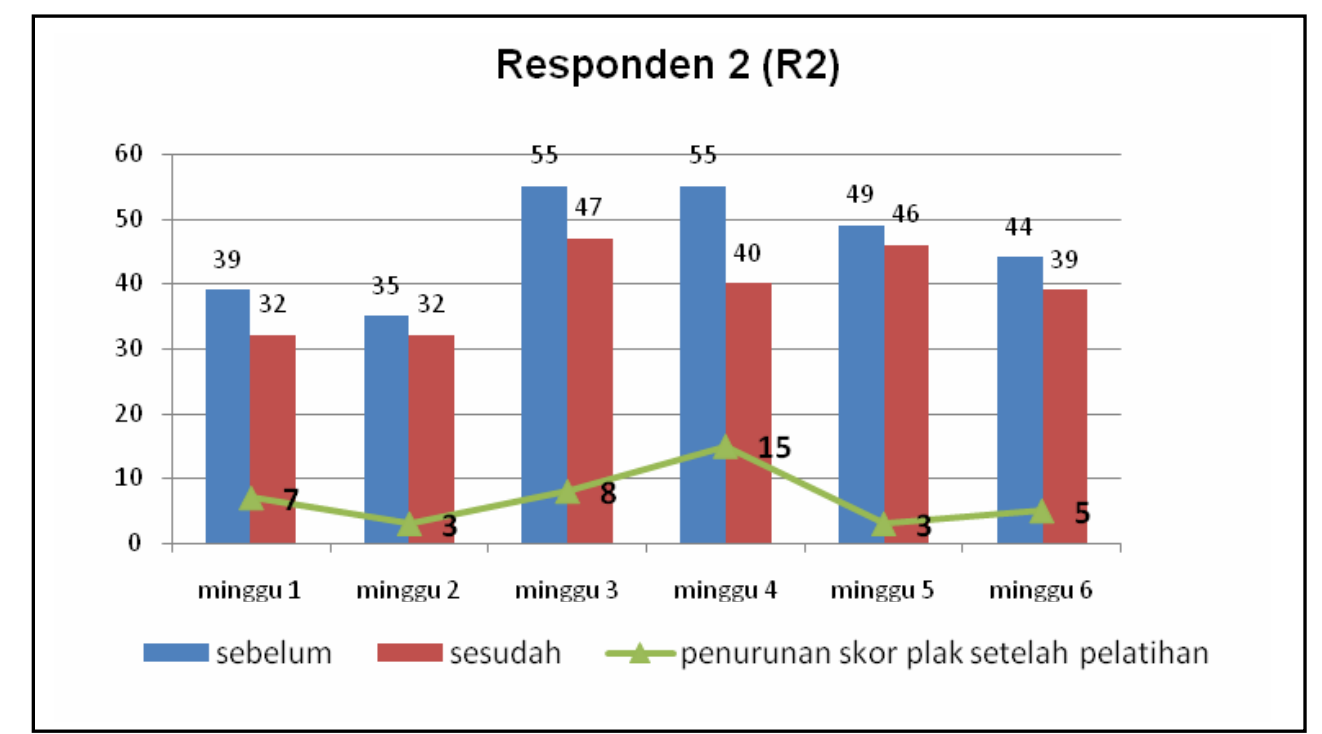

Gambar 2. Status kebersihan gigi dan mulut sebelum dan sesudah R2

\section{Reponden 3 (R3)}

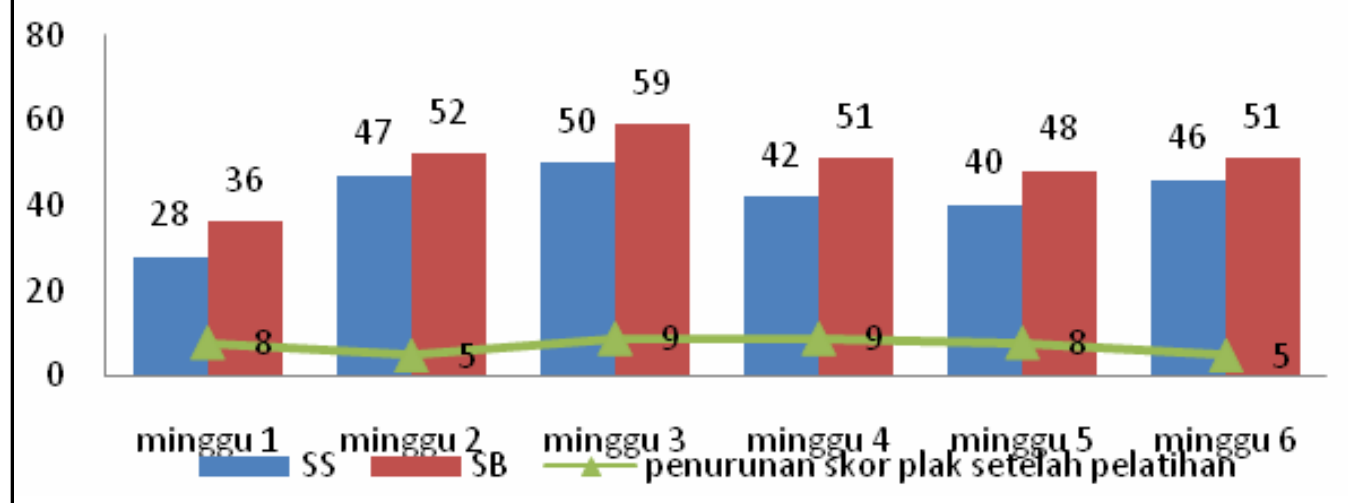

Gambar 3. Status kebersihan gigi dan mulut sebelum dan sesudah R3 
Gambar 3 menunjukkan status kebersihan gigi dan mulut R3 setelah dilakukan pelatihan selama 6 minggu, didapatkan rerata status kebersihan mulut yaitu 42 (kategori sedang). Rerata penurunan skor plak setiap minggu setelah pelatihan yaitu 7. Bagian permukaan gigi yang masih terdapat penumpukan plak setelah kegiatan menggosok gigi yaitu permukaan gigi sisi lingual segmen $4,5,6$, sisi palatal 1, 2, 3, sisi bukal segmen 4,6 dan labial segmen 2. R3 mampu membersihkan plak gigi dengan baik pada sisi permukaan oklusal segmen 6, 4 dan labial segmen 5 .

Gambar 1, 2 dan 3 menunjukkan ke-3 responden setelah mendapatkan pelatihan didapatkan penurunan plak yang masih rendah, rerata penurunan skor plak ke-3 responden yaitu 7 . Ketiga responden tersebut sebagian besar mampu membersihkan perlekatan plak secara baik yaitu pada permukaan gigi sisi oklusal dan sisi labial. Setelah mendapatkan pelatihan selama 6 minggu ke-3 responden didapatkan rerata status kebersihan gigi dan mulut yaitu pada kategori sedang $\mathrm{R} 1$ dan R2, R3 pada kategori buruk.

\section{PEMBAHASAN}

Pelatihan menggosok gigi dengan penerapan Program Pembelajaran Individual (PPI) yang dilakukan selama 6 minggu dapat menurunkan skor plak, hasil penelitian ini sejalan dengan Syama (2003) yang menyebutkan program supervisi menggosok gigi dan pendidikan kesehatan gigi yang diberikan anak Down syndrome efektif mengurangi skor plak. ${ }^{15}$ Kegiatan menggosok gigi merupakan tindakan mekanis untuk menghilangkan plak gigi, selain itu kegiatan tersebut bertujuan untuk membersihkan gigi dari makanan, debris dan pewarnaan serta menstimulus jaringan gingiva. ${ }^{16,17}$

Penurunan skor plak ke-3 responden setelah mendapatkan pelatihan selama 6 minggu didapatkan skor rata-rata yaitu 7 , penurunan skor plak yang rendah ini kemungkinan disebabkan oleh beberapa faktor. Hasil observasi peneliti beberapa faktor penyebab diantaranya yaitu: responden saat menggosok gigi tekanan gosok kurang mampu membersihkan perlekatan plak, yang ditandai dengan terlihatnya warna merah (disclosing solution) menempel dipermukaan gigi khususnya pada sisi permukaan gigi palatal, lingual maupun bukal, kecenderungan responden lebih kuat menggosok gigi sisi permukaan gigi labial dan oklusal. R2 dan R3 frekuensi menggosok gigi ditiap permukaan kurang dari 5 kali gosok, tekanan gosok kurang, beberapa permukaan gigi yang terlewat tidak disikat khususnya pada sisi palatal, lingual dan bukal, serta ketepatan peletakkan sikat yang tidak tepat ditiap permukaan gigi. Faktorfaktor tersebut yang menyebabkan pembersihan plak tidak maksimal sehingga menyebabkan status kebersihan gigi dan mulut masih rendah. Ditinjau dari faktor karakteristik dasar responden pada R1 memiliki kemampuan motorik halus yang baik, R2 memiliki kemampuan motorik halus yang kurang dan R3 memiliki motorik halus yang baik tetapi responden sangat tidak fokus saat melakukan kegiatan gosok gigi. Hasil penelitian ini mendukung penelitian sebelumnya yang menyatakan bahwa kegiatan menyikat gigi efektif menghilangkan perlekatan plak dengan memperhatikan:1) tepat memilih sikat, 2) tepat cara menyikat gigi, 3) tepat waktu menyikat gigi, 4) tepat lama menyikat gigi, 5) teliti sehingga semua bagian gigi bersih dari plak gigi. ${ }^{17}$ Pada anak disabilitas intelektual hasil penelitian menunjukkan bahwa faktor lain yang mempengaruhi keterampilan responden membersihkan plak gigi yaitu faktor karakteristik dasar anak khususnya kemampuan motorik halus. Pelatihan menggosok gigi dengan penerapan Program Pembelajaran Individual (PPI) terlihat jelas permasalahan tiap responden khususnya kemampuan membersihkan plak gigi ditiap permukaan gigi, hal ini memberikan dampak saat membuat rancangan pelatihan dan menentukan metode dalam pelatihan menggosok gigi pada kelompok ini.

\section{KESIMPULAN}

Pelatihan cara menggosok gigi menggunakan pendekatan Program Pembelajaran Individual (PPI) berpengaruh meningkatkan status kebersihan gigi dan mulut pada anak disabilitas intelektual sedang hal ini ditunjukkan dengan adanya penurunan skor plak. 


\section{DAFTAR PUSTAKA}

1. Peraturan Menteri Negara Pemberdayaan Perempuan dan Perlindungan Anak RI Nomor 10 tahun 2011

2. Wantah J. Pengembangan kemandirian anak tunagrahita mampu latih. Departemen Pendidikan Nasional Dirjen Pendidikan Tinggi Direktorat Ketenagaan. Jakarta; 2007.

3. DSM-5. Diagnostic and statistical manual of mental disorders (DSM-5). Washington DC: American Psychiatric Association; 2012.

4. Badan Pusat Statistik (BPS). Survai demografi dan kesehatan Indonesia 2002-2003; 2003.

5. Kemenkes. Pedoman pelayanan kesehatan anak di Sekolah Luar Biasa (SLB) bagi Petugas Kesehatan; 2010.

6. Mahmudah S. Perubahan perilaku kebersihan diri pasca pelatihan motorik halus: studi terhadap anak tunagrahita sedang di SLB C "Dharma Wanita" Lebo Sidoarjo. Tesis. Tidak diterbitkan. Surabaya: Universitas Airlangga; 2004.

7. Departemen Pendidikan Nasional. Standar kompetensi dan kompetensi dasar program khusus bina diri. Jakarta; 2007.

8. Shyama M, Al-Mutawa SA, Honkala S, Honkala E. Oral Hygiene and periodontal conditions in special needs children ang young adults in kuwait. J Disabil Oral Health. 2000; 1: 13- 19.

9. Carranza FA. Glickman's Clinical Periodontology, $10^{\text {th }}$ ed. Philadelphia: Sounders Company; 2006.
10. McCracken GI, Janssen J, Swan M, Steen $\mathrm{N}$, de Jager M, Heasman PA. Effect of brushing force and time on plaque removal using a powered toothbrush. J Clin Periodontal. 2003 May; 30(5): 409 - 413.

11. Gehrig N, Willman D. Foudation of periodontics for the dental hygiene ${ }^{2 n d}$ ed. USA; 2008.

12. Rochyadi E, Alimin Z. Pengembangan program pembelajaran individual bagi anak tunagrahita. Departemen Pendidikan Nasional Dirjen Pendidikan Tinggi Direktorat Ketenagaan. Jakarta; 2005.

13. Wantah J. Pengembangan kemandirian anak tunagrahita mampu latih. Departemen Pendidikan Nasional Dirjen Pendidikan Tinggi Direktorat Ketenagaan. Jakarta; 2007.

14. Delphie B. Pembelajaran anak berkebutuhan khusus. Bandung: Refika Aditama; 2006.

15. Shyama M, Al-Mutawa SA, Honkala S, Honkala E. Supervised toothbrusing and oral health education program in kuwait for children and young adulth with down syndrome. Spec Care Dentist. 2003; 23(3): 94 - 99.

16. Apiou J, Gueguen MM, Doleux S, BonnauerreMallet M. Evaluation of a new tootbrush concept with regard to bacterial elimination. $\mathrm{J}$ Clin Periodont. 1994; 21: 347 - 350.

17. Sriyono N. Pengantar ilmu kedokteran gigi pencegahan. Yogyakarta. Medika Fakultas Kedokteran UGM; 2007. 